\title{
Myocardial infarction in car assembly workers
}

\author{
P. J. BAXTER, W. G. WHITE, C. F. B. SANDERSON, G. M. BARNES, \\ C. S. BAXTER, and ROY M. ACHESON \\ Centre for Extension Training in Community Medicine, London School of Hygiene and \\ Tropical Medicine, and British Leyland UK Ltd, Assembly Plant, Cowley, Oxford
}

\begin{abstract}
Baxter, P. J., White, W. G., Sanderson, C. F. B., Barnes, G. M., Baxter, C. S., and Acheson, R. M. (1976). British Journal of Industrial Medicine, 33, 1-8. Myocardial infarction in car assembly workers. The incidence of myocardial infarction and the return to work of survivors were studied among the employees of an English car assembly plant by analysing 12811 medical records of persons employed during the seven years between January 1966 and December 1972. The standardized morbidity ratio of myocardial infarction found in this study calculated on the basis of incidence rates reported by Kinlen (1973) for the Oxford community in which the factory was situated was 90 . The standardized morbidity ratio from production line workers only was 66 and that for the monthly paid staff 272 . Of the production line workers who survived the attack $22(90 \%)$ returned to their previous jobs without undue difficulty and with two exceptions within four months of the onset of their illness; there was no relation between length of absence and age at the time of attack. These findings suggest that workers in mass production jobs such as car assembly are not at special risk from myocardial infarction, and most of those who survive a heart attack are able to return to their former work. Taken with Kinlen's (1973) study and that of Armstrong et al. (1972) in Edinburgh, they also bear out mortality data by indicating that in Oxfordshire the incidence of coronary heart disease is lower than the British average.
\end{abstract}

The assembly lines of the automobile factory provide an opportunity to study the effects on the health of the individual of a mass production job. The car body shell and its components are mechanically conveyed to and from the workers who perform predetermined repetitive tasks. It has been argued that the tension caused by the mechanical pacing and the monotony of the work may cause psychological stress and that this increases with age. According to Griew (1971) older persons do not cope well with mass production jobs and Murrell (1962) has said that middle-aged or elderly workers usually prefer jobs which are slower and less exacting. Many authors (for example, Jenkins, 1971; Sales and House, 1971) have suggested that psychological stress and lack of job satisfaction may be contributory factors in the aetiology of myocardial infarc- tion, although this interrelationship is neither firmly established nor clearly understood.

Nowadays, as Nagle, Gangola, and PictonRobinson (1971) have shown, most survivors of a myocardial infarction are able to return to the same occupation, except severe cases with physical sequelae or those with psychological disability; indeed, advances in coronary care and rehabilitation enable a high proportion of cases to return to work within a few months. However, advanced age and a blue collar job are possible delaying factors according to Shapiro, Weinblatt, and Frank (1972).

The data presented in this paper were originally collected as part of a much larger study of the care of acute coronary heart disease. Nevertheless, they are suitable for testing two hypotheses derived from this review of the literature and formulated by one of us 
(PJB). The first is that if stress precipitates myocardial infarction and working on an assembly line is stressful, then the incidence of myocardial infarction among those working on the production line will be higher than in those working elsewhere in the factory; the second is that in order to avoid or postpone returning to a stressful situation, the rate of return among production line employees to their previous job will not be as high as it is among the rest of the labour force. Neither hypothesis was sustained.

\section{Method}

\section{Population at risk}

The population at risk were all men employed between 1 January 1966 and 31 December 1972, who had retained their job for at least 12 months in a large Oxford assembly plant which was primarily concerned with the production of family cars and small vans.

For the purpose of analysis, the work force was classified into two major groups, production line workers and non-production line workers. The non-production line group was further sub-divided into employees paid on a monthly basis, foremen, and others, such as policemen, drivers, storemen, plant maintenance staff, etc.

The production line group was defined as those manual workers directly involved in the assembly of component parts to the body shell and the completion of the car from the beginning to the end of the assembly line.

\section{Source and collection of information}

Data for the study were taken from the records at the medical centre in the plant, where a card is kept for every employee. These cards are used to record details of identification, job, illness at work, and medical causes of absence, and are kept for seven years after the employee has left. In order to assist the retrieval of information, it is the practice of the plant physicians to record in coloured ink details of serious illnesses, of which myocardial infarction is one. Data for the study were abstracted by a team of State Registered nurses whose work was supervised by two full-time plant physicians who had worked in the factory for many years.

The medical card of everyone employed during the period of study was examined, and the following details were abstracted: (a) name; (b) sex; (c) date of birth; (d) clock number; (e) department; (f) occupation; (g) date of commencement of employment; (h) date of termination of employment.

The nurses who abstracted the data put to one side the records of employees who had been diagnosed as having had a myocardial infarction. Clinical details of the case were then entered by the plant physicians on special forms. For each case the following details were recorded: (i) time, date and place of attack; (j) evidence for diagnosis: (necropsy, ECG, enzymes, clinical history); (k) for those who survived an acute episode: place of treatment; (1) for employees who returned to work: the date of return, part or full time, job on return to work; $(\mathrm{m})$ for employees who did not return to work: reason for leaving, and/or time and date of death.

Records in the Personnel Department proved helpful when any information was missing or inconsistent; these records also provided information about employment history in cases of myocardial infarction.

\section{Criteria for diagnosis}

The medical centre routinely treats only minor ailments and emergencies; other cases are referred either to hospital or to the patient's general practitioner. Employees are required to provide written details of major illness on return to work; in the event of death off the factory premises, the medical centre is notified by the Personnel Department. Thus, a possible case of myocardial infarction can be identified through information provided by at least one of the following: (1) a certificate of incapacity; (2) a letter from the hospital or general practitioner; (3) a death certificate.

A diagnosis provided through any one of the above sources was accepted, and a note was made when the characteristic history was supported by ECG and/or serum enzyme changes. Necropsy records were not directly available to the investigators but copies of death certificates were examined in the Personnel Department.

\section{Results}

\section{Population at risk}

The total number of employees identified by studying the medical record cards for the seven-year period 1966-72 was 14280 . Of these, 219 (2\%) were excluded because their records lacked sufficient information. Women were also excluded because they formed only a small proportion of the work force and there were no known heart attacks among them between 1966-72. This left available for study a male population of 12811 .

Biennial counts of the number of male employees

TABLE 1

Biennial Tally of Numbers of Male Employees (ON 1 JULY)

\begin{tabular}{l|cccc}
\hline Employees & 1966 & 1968 & 1970 & 1972 \\
\hline $\begin{array}{l}\text { Production workers } \\
\begin{array}{l}\text { Non-production } \\
\text { workers }\end{array}\end{array}$ & 4287 & 3895 & 3765 & 5059 \\
\hline Total & 4437 & 4039 & 3831 & 3883 \\
\hline
\end{tabular}

TABLE 2

Mean Age and Mean Numbers Employed by OCCUPATION (MALES ONLY)

\begin{tabular}{|c|c|c|c|c|}
\hline & $\begin{array}{l}\text { Production } \\
\text { line }\end{array}$ & Foremen & Monthly & Others \\
\hline $\begin{array}{l}\text { Mean age } \\
\text { Mean numbers }\end{array}$ & $\begin{array}{r}38 \\
4252\end{array}$ & $\begin{array}{r}45 \\
410\end{array}$ & $\begin{array}{r}43 \\
208\end{array}$ & $\begin{array}{r}43 \\
3430\end{array}$ \\
\hline
\end{tabular}




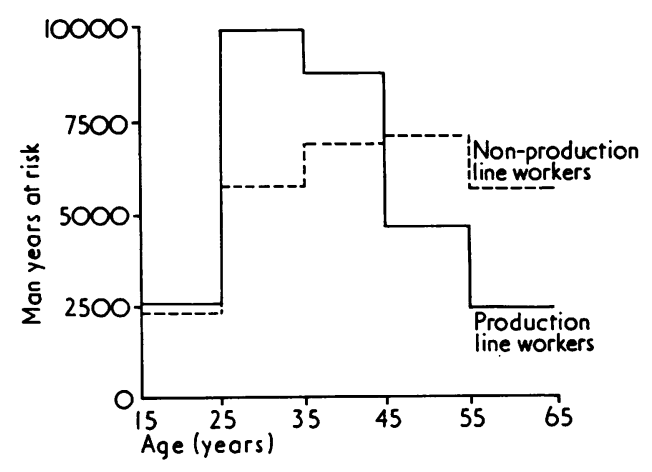

FIG. 1 Distribution by age of labour force according to whether or not members were production line workers, expressed in terms of man years at risk.

are given in Table 1 and their occupations and average ages in Table 2 . The distribution of manyears at risk for production and non-production line workers was calculated using a modification of the method described by Hill (1972) and Fig. 1 shows that the production line workers tended to be younger. The average annual turnover rate among men who remained in employment for longer than a year was $5 \%$ for production line workers and $6 \%$ for all non-production line workers.

\section{Incidence of myocardial infarction}

There were 131 attacks of myocardial infarction in the study population over the seven years, 103 of which were first attacks. The proportion of all cases which were first attacks was similar for production line and non-production line workers (Table 3).

Test results confirming the diagnosis had been recorded in $47 \%$ of attacks, and death certificate details were obtained in a further $37 \%$. In the remaining $16 \%$, the patient had been treated as a case of myocardial infarction by the hospital or general practitioner concerned and their diagnosis was accepted, although confirmatory evidence was not available to the investigators.

The age-specific rates for all cases of myocardial infarction were calculated and compared on an ageadjusted basis with those from a study of the incidence of attacks of myocardial infarction in 1967 for the general population in and around Oxford (Kinlen, 1969, 19721 1 1973).

Using Kinlen's data as a base standardized morbidity ratios were then used to compare the incidence between occupational groups in the factory.

${ }^{1}$ Both in his thesis (1969) and his published report (1973) Kinlen presented his data in age groups 20-29, 30-39 years, etc. However he kindly recalculated them for us in the form 25-34, 35-44, etc. (Kinlen, personal communication, 1972).

TABLE 3

Total Number of Cases by Occupation and First Attack

\begin{tabular}{c|c|c|c|c|c}
\hline \multicolumn{2}{c|}{ Production line workers } & \multicolumn{2}{c|}{ Non-production line workers } & \multicolumn{2}{c}{ Total no. of cases per year } \\
\hline First attack & All cases & First attack & All cases & First attack & All cases \\
\hline 28 & 36 & 75 & 95 & 103 & 131 \\
\hline
\end{tabular}

TABLE 4

Incidence Per 1000 Man Years at Risk and Total Number of Cases, First Attack Only 1966-72, BY OCCUPATION

\begin{tabular}{|c|c|c|c|c|c|}
\hline \multirow{2}{*}{ Occupation } & \multirow{2}{*}{ Production line } & \multicolumn{3}{|c|}{ Non-production line } & \multirow{2}{*}{ Overall } \\
\hline & & Foremen & Monthly Paid & Others & \\
\hline $\begin{array}{r}0-24 \\
25-34 \\
35-44 \\
45-54 \\
55-64 \\
65-74\end{array}$ & $\begin{array}{l}-\overline{0.2^{*}} \\
0 \cdot 7 \\
2 \cdot 1 \\
4 \cdot 0 \\
-\end{array}$ & $\begin{array}{l}\bar{Z} \\
\overline{\bar{c}} \\
4 \cdot 3^{*} \\
3 \cdot 1^{*} \\
-^{*}\end{array}$ & $\begin{array}{c}\bar{Z} \\
\bar{Z} \\
5 \cdot 9^{*} \\
24 \cdot 3 \\
-\end{array}$ & $\begin{array}{l}- \\
0 \cdot 9 \\
2 \cdot 8 \\
8 \cdot 0 \\
-\end{array}$ & $\begin{array}{l}\overrightarrow{0 \cdot 1^{*}} \\
0 \cdot 7 \\
2 \cdot 7 \\
7 \cdot 0 \\
4 \cdot 4^{*}\end{array}$ \\
\hline Total & 28 & 6 & 9 & 60 & 103 \\
\hline
\end{tabular}

* Rates based on fewer than five cases 
In using this ratio, the distinction between first and subsequent attacks was dropped, but this did not materially affect the shape of the age-specific distribution (Tables 4 and 5). The standardized morbidity ratio for the whole factory derived thus was 90 (Table 6).
Pattern of attacks

The standardized morbidity ratio among production line workers was 66 compared with Kinlen's community rates, whereas for non-production line workers it was 107. Age specific rates for these two groups are given in Table 7 and Fig. 2. It can be seen

TABLE 5

InCidence Per 1000 Man Years at Risk and Total Number of Cases, All Cases 1966-72, by Occupation

\begin{tabular}{|c|c|c|c|c|c|}
\hline \multirow{2}{*}{$\begin{array}{c}\text { Age } \\
\text { (years) }\end{array}$} & \multirow{2}{*}{ Production line } & \multicolumn{3}{|c|}{ Non-production line } & \multirow{2}{*}{ Overall } \\
\hline & & Foremen & Monthly paid & Others & \\
\hline $\begin{array}{l}25-34 \\
35-44 \\
45-54 \\
55-64 \\
65-74\end{array}$ & $\begin{array}{l}0 \cdot 2^{*} \\
0 \cdot 8 \\
2 \cdot 3 \\
6 \cdot 4 \\
-\end{array}$ & $\begin{array}{l}\text { - } \\
5 \cdot 7^{*} \\
4 \cdot 6^{*} \\
\text { - }^{*}\end{array}$ & $\begin{array}{c}- \\
\overline{8 \cdot 8^{*}} \\
31 \cdot 2 \\
-\end{array}$ & $\begin{array}{r}- \\
1 \cdot 2 \\
3 \cdot 0 \\
10 \cdot 3 \\
-\end{array}$ & $\begin{array}{l}0 \cdot 1^{*} \\
0 \cdot 9 \\
3 \cdot 1 \\
9 \cdot 4 \\
8 \cdot 8^{*}\end{array}$ \\
\hline Total & 36 & 8 & 12 & 75 & 131 \\
\hline
\end{tabular}

* Rates based on fewer than five cases

TABLE 6

Age-SPeCific Number of CASES OF Myocardial INFARCTIONS IN Men Under 65 (WHOLE FACTORY, 1966-72)

\begin{tabular}{|c|c|c|c|c|}
\hline \multirow{2}{*}{$\begin{array}{c}\text { Age } \\
\text { (years) }\end{array}$} & \multirow{2}{*}{ Man-years at risk } & \multicolumn{2}{|c|}{ Myocardial infarctions } & \multirow{2}{*}{$\begin{array}{c}\text { Standardized } \\
\text { ratio } \%\end{array}$} \\
\hline & & Observed no. & Expected no.* & \\
\hline $\begin{array}{l}25-34 \\
35-44 \\
45-54 \\
55-64\end{array}$ & $\begin{array}{r}15726 \cdot 26 \\
15648 \cdot 20 \\
11772 \cdot 50 \\
8170 \cdot 40\end{array}$ & $\begin{array}{r}2 \\
14 \\
36 \\
77\end{array}$ & $\begin{array}{r}4 \cdot 7 \\
21 \cdot 8 \\
41 \cdot 3 \\
75 \cdot 4\end{array}$ & $\begin{array}{r}43 \\
64 \\
87 \\
102\end{array}$ \\
\hline Total & $51317 \cdot 40$ & 129 & $143 \cdot 2$ & 90 \\
\hline
\end{tabular}

*Based on rates derived from Kinlen (1973)

TABLE 7

Observed and Expected Numbers of Cases for Production Line AND NON-PRODUCTION LINE WORKERS (1966-72)

\begin{tabular}{|c|c|c|c|c|c|c|c|c|}
\hline \multirow{3}{*}{$\begin{array}{c}\text { Age } \\
\text { (years) }\end{array}$} & \multicolumn{4}{|c|}{ Production line } & \multicolumn{4}{|c|}{ Non-production line } \\
\hline & \multirow{2}{*}{$\begin{array}{c}\text { Man years } \\
\text { at risk }\end{array}$} & \multicolumn{2}{|c|}{ Myocardial infarctions } & \multirow{2}{*}{$\begin{array}{l}\text { Standardized } \\
\text { ratio } \%\end{array}$} & \multirow{2}{*}{$\begin{array}{c}\text { Man years } \\
\text { at risk }\end{array}$} & \multicolumn{2}{|c|}{ Myocardial infarctions } & \multirow{2}{*}{$\begin{array}{c}\text { Standardized } \\
\text { ratio } \%\end{array}$} \\
\hline & & $\begin{array}{c}\text { Observed } \\
\text { no. }\end{array}$ & $\begin{array}{c}\text { Expected } \\
\text { no.* }^{*}\end{array}$ & & & $\begin{array}{c}\text { Observed } \\
\text { no. }\end{array}$ & $\begin{array}{c}\text { Expected } \\
\text { no.* }\end{array}$ & \\
\hline $\begin{array}{l}25-34 \\
35-44 \\
45-54 \\
55-64\end{array}$ & $\begin{array}{l}9948.9 \\
8746.6 \\
4690.4 \\
2494.6\end{array}$ & $\begin{array}{c}2 \\
7 \\
11 \\
16 \dagger\end{array}$ & $\begin{array}{r}3 \cdot 0 \\
12 \cdot 2 \\
16 \cdot 4 \\
23 \cdot 0\end{array}$ & $\begin{array}{l}66 \cdot 7 \\
57 \cdot 4 \\
67 \cdot 1 \\
69 \cdot 6\end{array}$ & $\begin{array}{l}5777 \cdot 3 \\
6901 \cdot 6 \\
7082 \cdot 1 \\
5675 \cdot 8\end{array}$ & $\begin{array}{c}0 \\
7 \\
25 \\
61 \dagger\end{array}$ & $\begin{array}{r}1 \cdot 7 \\
9 \cdot 7 \\
24 \cdot 8 \\
52 \cdot 2\end{array}$ & $\begin{array}{c}0 \\
72 \cdot 2 \\
100 \cdot 8 \\
116 \cdot 8\end{array}$ \\
\hline Total & 25880.5 & $36 \dagger$ & $54 \cdot 6$ & 66 & 25436.8 & $93 \dagger$ & $86 \cdot 7$ & 107 \\
\hline
\end{tabular}

* Based on rates derived by Kinlen (1973)

$\dagger$ Differences between production line workers and non-production line workers significant at the $5 \%$ level 


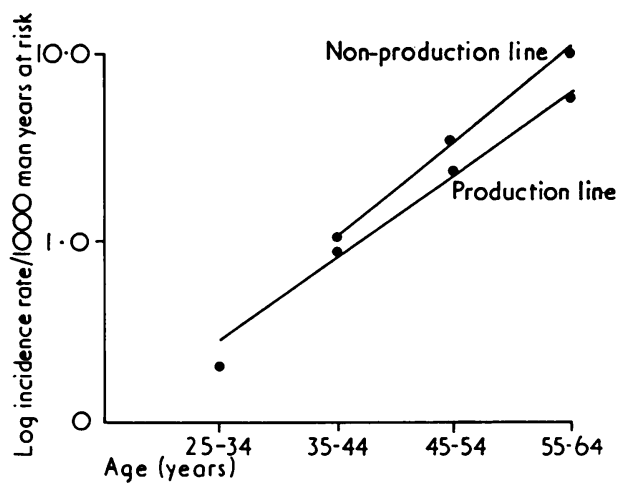

FIG. 2 Logarithm of incidence of myocardial infarction in production line workers and the rest of the labour force, plotted against age. It is clear that the incidence is consistently lower in the former group. The data from which the graph is plotted are given in Table 5 .

that the differences are consistent throughout the age range. Using the technique of Mantel and Haenszel, (1959) the incidence in non-production line workers was estimated as being 1.54 times higher than that in production line workers $(P \simeq 0.5)$.

Other studies have shown that foremen tend to have higher incidence rates of myocardial infarction than the men for whom they are responsible. Since in Table 7 and Fig. 2 foremen were classified as non-production line workers, and an excessively high incidence among this subgroup could be responsible for the observed difference between the larger groups, the foremen were treated as a separate group and the data reanalysed. This had next-to-no effect, raising the standardized morbidity ratio for non-production line workers from 107 to 109 . The standardized morbidity ratio for monthly paid workers was 272 , but excluding them left a ratio for non-production workers of 96. Recalculation of the standardized morbidity ratios by five year age groups against interpolated data derived from Kinlen made little difference either; the standardized morbidity ratio for non-production workers increased from 66 to 69 , while that for production workers was 108 as compared with 107.

\section{Case fatality}

The number of fatal cases on and off the production line are shown in Table 8. For the whole factory, the fatality rate was $38 \%$, much lower than Kinlen's figure of $50 \%$. Thirty attacks occurred at work during the period of the study, of which only six were fatal.

\section{Duration of absence from work}

Only one of the production line cases, a man who
TABLE 8

Case Fatality by OcCupation and Nature of AtTack

\begin{tabular}{l|rl|rr|rr}
\hline \multicolumn{1}{c|}{ Employees } & First attack & $\begin{array}{c}\text { Subsequent } \\
\text { attacks }\end{array}$ & Overall \\
\cline { 2 - 5 } $\begin{array}{l}\text { Production line } \\
\begin{array}{l}\text { Non-production } \\
\text { line }\end{array}\end{array}$ & 9 & $(31)$ & 4 & $(57)$ & 13 & $(36)$ \\
Overall & 27 & $(36)$ & 10 & $(48)$ & 37 & $(39)$ \\
& 36 & $(35)$ & 14 & $(50)$ & 50 & $(38)$ \\
\hline
\end{tabular}

Percentages are given in parentheses

had his attack at the age of 41 years, left work for good, and he was presumably disabled. In two other cases, about a year elapsed between the date of the attack and the date of returning to work, a period greatly in excess of the rest of the group. The other 20 men had all returned within about four months, with a median length of absence of 81 days, a mean of 86 and a standard deviation of 21 days (Fig. 3). The data were examined to see whether the duration of absence was a linear function of either age at the time of infarction or the length of time worked on the assembly line, but in neither case was such a relationship found.

Off the production line, five employees left after surviving an attack, and one had been away for two years when the study was carried out. The youngest of these at the time of his attack was 56. Two cases were away for more than a year before they returned, but of the remaining 50 cases, 37 were back at work within four months. The median time off work was

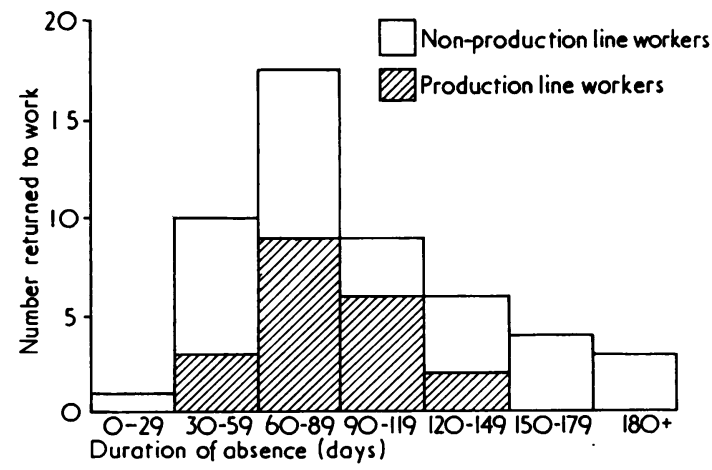

FIG. 3 Distribution of time spent in recovery from a myocardial infarction before resumption of work. The shaded bars denote the return to work of the 20 production line workers and are superimposed on the unshaded bars of the 52 non-production line workers. It is clear that the distributions for the two groups are similar. 
75 days, but the mean was 94 days and the standard deviation 49 days.

\section{Work taken up by survivors}

This is presented in detail for production line workers only. Nine of them were temporarily recommended for lighter duties, but all members of the group eventually returned to their original job, except two who were transferred to other departments where the work was less arduous. All of them had satisfactory attendance records.

\section{Discussion}

In this survey, use was made of a carefully kept series of medical records to obtain information about the incidence of a disease, acute myocardial infarction, in a defined industrial population over a seven-year period, which had elapsed before the study itself began. Although the events under consideration were in the past, the design allowed a group of healthy men to be defined, and followed through time until they fell ill. It is therefore that of a prospective survey.

The identification of cases, using this method, was probably very efficient. Unlike incidence studies of the general population which depend on the cooperation of individuals, such as that carried out in Framingham, Massachusetts, where from the outset only some $66 \%$ of the population participated in the study, it was possible to keep all the defined population under surveillance by the use of comprehensive records. However, cases could have been missed for a variety of reasons. The reason for sickness absence could have been misrecorded when the men returned to work, particularly if the information provided by the general practitioner were scanty; or recorded cases could have been missed by the nurses who carried out the search. It was also possible that men left the factory immediately after falling ill, so that no diagnosis would have been received at the medical centre. The number of employees in the last category is not likely to have been great because, whether the patient died or survived, he or his relatives would have stood to have suffered financial loss by failing to advise the employers of the attack. On the question of potential over-recording, $16 \%$ of the 131 attacks were accepted in the absence of confirmatory evidence. However, provided that neither over-nor under-recording was affected by whether the man was on the production line or not, the large differences in the two occupation groups with respect to incidence rate still stand. Thus it seems not only that the working hypothesis which initiated the study must be rejected, but that a significant difference in the opposite direction from our expectations must be explained.

One possible source of bias would have been the removal of production-line workers with angina to non-production jobs. This was not the policy of the factory medical department, and of the 27 production-line workers who had a record of being angina cases during the period of study, 20 were known to have continued in the same job. Another four had stayed on the line but with less arduous work; one left the factory; one moved to nonproduction work, and we had no information about the subsequent occupation of the remaining case. Change of job within the factory among men with a high risk of myocardial infarction is thus unlikely to be the reason for our results.

Two studies of incidence of myocardial infarction have been made in general populations in Britain in recent years. The first to be published in the general literature was from Edinburgh (Armstrong et al., 1972) the second was carried out in Oxfordshire in $1966-67$ by Kinlen $(1969,1973)$ and will have included some of the cases in this study. Although Kinlen's rates are not wholly independent of ours, it is of considerable interest that the age-adjusted incidence rates in the two Oxford studies are very similar to each other, yet very much lower than those reported in Edinburgh. The low rates reported by Kinlen have been ascribed to the very rigorous diagnostic criteria he imposed and doubtless these will have contributed to the difference reported between Oxford and Edinburgh. However, our criteria were much more akin to those of the Scottish workers, so that, while the close similarity between our incidence rate and that reported by Kinlen tends to confirm the view that incidence in Oxfordshire is substantially lower than that in Edinburgh, it also raises the question of whether we did indeed miss some cases. It is, of course, a selected population; all employees including management and office staff are subjected to a medical examination which includes measurement of blood pressure before they are taken on. As we have already pointed out, however, in the absence of bias we are still left with a quite unexpectedly low incidence of myocardial infarction among the men working on the production line.

The idea that psychological stress constitutes a risk for coronary heart disease dates back some 20 years. A leading proponent of this view has been Meyer Friedman who with his colleagues has pursued a line of investigation which has identified personal drive and ambition, characteristics which they describe as 'behaviour pattern $\mathrm{A}$ ', with an increased probability of developing a myocardial infarction (Friedman and Rosenman, 1959; Rosenman et al., 1970; Jenkins, Rosenman, and Zyzanski, 1974). Syme, a sociologist, studied people whom he believed to be under stress by identifying those who had, because of success, risen through the social strata. In two surveys (Syme, Hyman, and Enterline, 1964; Syme, Borhani, and Buechley, 1965) 
he found such people to have a higher incidence of myocardial infarction than those whose social status was stable or had fallen. It may be that Friedman and his colleagues by directly identifying ambition in individuals and Syme by studying the consequences of an ambition in groups were both measuring the same thing. However, Tyroler and Cassell (1964) showed that, when industrialization was brought to a rural community, those members of that community who became involved in industry developed myocardial infarction more frequently than those not so involved. In the last instance, it could be argued that only the ambitious allowed themselves to become employed by industry, but there is a good case for suggesting that they were more passive than Friedman's A types, or the 'social successes' which Syme describes. Either hypothesis might be applied to production line employees in a motor factory. It could be suggested that they are willing to tolerate a tedious job in order to earn the extra money which will advance their social status, or that the relentless moving of the line and the demands of maintaining productivity impose stress upon them.

At all events the present findings are incompatible with the hypothesis that assembly line work in this factory induces a kind of stress which precipitates myocardial infarction. One possible explanation for this is that it is because, as Goldsmith and Tan (1975) have shown, the tasks they are required to perform are a good deal more physically arduous than sedentary office work. The findings of Morris et al. (1953), which have subsequently been confirmed by many others, is now widely accepted as showing that exertion protects against a high incidence of myocardial infarction.

Staff who were paid monthly, including those who had executive responsibility, had a standardized morbidity ratio of 272 when compared with Kinlen's rates. Comparisons between different factories in different cultures are difficult to interpret, but this result is at variance with the work of Pell and D'Alonzo (1963) who made an extensive study of the epidemiology of coronary heart disease in a large manufacturing corporation in the USA, and found lower incidence rates among executive staff than among foremen or clerical supervisors.

Whatever the factors at work may be, it is important to bear in mind that the majority of a man's life is spent away from his job, and in the instance of Oxfordshire it is spent in an environment where the risk of developing myocardial infarction is relatively low. The reason for this is obscure, and until it has been clarified the relationship between the risk factors in the working environment and the total environment cannot be satisfactorily clarified either.

Return to work of assembly workers

The return to work of $90 \%$ of assembly line workers within four months of their attacks is similar to the findings of other studies of return to work in general (for example, Royston, 1972; Groden, 1967) and again there was no evidence that the assembly line presented any special health hazards. Nor was duration of absence related either to age at the time of attack or to the length of time the man had previously been employed. Out of the 23 non-fatal attacks between 1966-72, one worker was presumed to be totally disabled and unable to return to work. In a study of 107 automobile production and supervisory workers in Detroit (Bruton and Jocz, 1957), seven were totally disabled and 15 were transferred to lighter work. On a percentage basis, the American study indicates a higher level of residual disability than the present study, but attitudes to the clinical management of coronary heart disease have changed considerably during the 18 years which have elapsed since Bruton and Jocz published their report.

It is a pleasure to express our gratitude to Professor R. S. F. Schilling for his support throughout the study. We also wish to thank Mrs C. Hesford, SRN, Mrs F. Lambden, SRN, and Mrs P. Wheeler, SRN for the part they played in data collection, and Mrs M. Potter for secretarial assistance. This study was carried out by $\mathrm{PJB}$ in partial fulfilment of the requirements for the MSc degree in occupational medicine of the University of London under the direction of Professor Acheson. The entire costs were borne by a grant from the Department of Health and Social Security to the London School of Hygiene and Tropical Medicine.

The paper was presented in part to the Society for Social Medicine at the University of Kent in Canterbury on 18 September 1975 .

\section{References}

Armstrong, A., Duncan, B., Oliver, M. F., Julian, D. G., Donald, K. W., Fulton, M., Lutz, W., and Morrison, S. L. (1972). Natural history of acute coronary heart attacks. A community study. British Heart Journal, 34, 67-80.

Bruton, M. F. and Jocz, M. W. (1957). Myocardial infarction in industrial workers. Industrial Medicine and Surgery, 26, 551-555.

Friedman, M. and Rosenman, R. H. (1959). Association of specific overt behaviour pattern with blood and cardiovascular findings. Journal of American Medical Association, 169, 1286-1296.

Goldsmith, R. and Tan, L. (1975). Physiological studies of energy output among car assembly workers. (Personal communication).

Griew, S. (1971). Occupational aspects of ageing. In Psychology at Work, edited by P. B. Warr, pp. 146-168. Penguin Books, London.

Groden, B. M. (1967). Return to work after myocardial infarction. Scottish Medical Journal, 12, 297-301.

Hill, I. D. (1972). Computing man years at risk. British Journal of Preventive and Social Medicine, 26, 132-134.

Jenkins, C. D. (1971). Psychological and social precursors 
of coronary disease. New England Journal of Medicine, 284, 244-285.

, Rosenman, R. H., and Zyzanski, S. J. (1974). Prediction of clinical coronary heart disease by a test for the coronary-prone behaviour pattern. New England Journal of Medicine, 290, 1271-1275.

Kinlen, L. J. (1969). A Community Study of Acute Myocardial Infarction and Sudden Death. Thesis for Doctorate in Philosophy, University of Oxford, Bodleian Library.

(1973). Incidence and presentation of myocardial infarction in an English community. British Heart Journal, 35, 616-622.

Mantel, N. and Haenszel, W. (1959). Statistical aspects of the analysis of data from retrospective studies of disease. Journal of National Cancer Institute, 22, 719-798.

Morris, J. N., Heady, J. A., Raffle, P. A. B., Roberts, C. G., and Parks, J. W. (1953). Coronary heart disease and physical activity of work. Lancet, 2, 1053-1057, 1111-1120.

Murrell, K. F. H. (1962). Industrial aspects of ageing. Ergonomics, 5, 147-153.

Nagle, R., Gangola, R., and Picton-Robinson, I. (1971). Factors influencing return to work after myocardial infarction. Lancet, 2, 454-456.

Pell, S. and D'Alonzo, C. A. (1963). Acute myocardial infarction in a large industrial population. Journal of the American Medical Association, 185, 831-839.
Rosenman, R. H., Friedman, M., Straus, R., Jenkins, C. D., Zyzanski, S. J., and Wurm, M. (1970). Coronary heart disease in the western collaborative group study. A follow-up experience of $4 \frac{1}{2}$ years. Journal of Chronic Diseases, 23, 173-190.

Royston, G. R. (1972). Short stay hospital treatment and rapid rehabilitation of cases of myocardial infarction in a district hospital. British Heart Journal, 34, 526-532.

Sales, S. M. and House, J. (1971). Job dissatisfaction as a possible risk factor in coronary heart disease. Journal of Chronic Diseases, 23, 861-873.

Shapiro, S., Weinblatt, E., and Frank, C. W. (1972). Return to work after first myocardial infarction. Archives of Environmental Health, 24, 17-26.

Syme, S. L., Borhani, N. O., and Buechley, R. W. (1965). Cultural mobility and coronary heart disease in an urban area. American Journal of Epidemiology, 82, 334-346.

_, Hyman, M. M., and Enterline, P. E. (1964). Some social and cultural factors associated with the occurrence of coronary heart disease, Journal of Chronic Diseases, 17, 277-289.

Tyroler, H. A. and Cassell, J. (1964). Health consequences of culture change: II. Effect of urbanization on coronary heart mortality in rural residents. Journal of Chronic Diseases, 17, 167-177.

Received for publication 1 May 1975. Accepted for publication 20 June 1975. 